\title{
UPLATNENIE VYBRANÝCH NÁSTROJOV CONTROLLINGU V RIADENÍ NÁKLADOV DOPRAVNÝCH PODNIKOV A ICH VYUŽITIE V REPORTINGU
}

\section{APPLICATION OF SELECTED CONTROLLING TOOLS IN COST MANAGEMENT OF TRANSPORT COMPANIES AND THEIR USE IN REPORTING}

Ol'ga Poniščiaková1 ${ }^{*}$, Eva Kicová2,

\begin{abstract}
Abstrakt
Z hl'adiska zvyšujúcej sa zložitosti podnikových systémov a ich využitia je nevyhnutným základom každej úspešnej cesty taký systém, ktorý integruje nielen spracovanie informácií, tvorbu plánov, ale aj analýzu a kontrolu. Vel'mi dôležitá je aj možnost' prijímat' správne a rýchle rozhodnutia, čím sa znižuje pravdepodobnost' možných rizík a nebezpečenstiev na minimum. Controlling je v tomto kontexte vel'mi dôležitým nástrojom pre podporu riadenia a rozhodovania. Príspevok prináša analýzu controllingových nástrojov s ohl'adom na ich uplatnenie v riadení dopravných spoločností. Dôraz je kladený najmä na controllingové riadenie nákladov, ich controllingovú kategorizáciu všpecifických podmienkach dopravných podnikov ako aj ich následné využitie pri riadení zisku. Pre dosiahnutie ciel'a boli využité viaceré metodológie, nielen pri čiastkových ciel'och - získavaní a spracovávaní teoretických poznatkov - ale aj pri d'alšom riešení, návrhoch praktického využitia vybraných nástrojov controllingu $v$ dopravných spoločnostiach. Predmetná problematika bola riešená $s$ využitím vybraných kvalitatívnych metód, opierajúcich sa o indukciu so snahou pozorovat', zist'ovat' pravidelnosti, vytvárat' závery a teórie za účelom získania naratívnych výstupov. Teoretické výstupy sú výsledkom spracovania dostupných poznatkov o controllingu a jeho vývoji, praktická rovina poskytuj výsledok vo forme návrhu uplatnenia vybraných nástrojov controllingu v podmienkach dopravných spoločností, pôsobiacich v Slovenskej republike. Príspevok možno považovat' za relevantný zdroj poznania a pochopenia riešenej problematiky, ponúka metodický návrh, uplatnitel'ný vo všeobecnosti pre podniky, ktorých manažment sa pre zavádzanie a využívanie controllingových nástrojov rozhodne.
\end{abstract}

Klíčová slova riadenie, doprava, controlling, náklady

Summary In view of the increasing complexity of business systems and their use, a necessary basis for any successful journey is a system that integrates not only information processing, planning, but also analysis and control. The ability to make the right and quick decisions is also very important, reducing the likelihood of potential risks and dangers to a minimum. It is a tool to support management and decision-making, it makes it easier for managers to make decisions. The paper presents an analysis of controlling tools with regard to their application in the management of transport companies. Emphasis is placed especially on controlling cost management, their controlling categorization in the specific

\footnotetext{
1 Žilinská univerzita v Žiline, Fakulta prevádzky a ekonomiky dopravy a spojov, Katedra ekonomiky, Univerzitná 1, 010 26, Žilina, Slovenská republika

2 Žilinská univerzita v Žiline, Fakulta prevádzky a ekonomiky dopravy a spojov, Katedra ekonomiky, Univerzitná 1, 010 26, Žilina, Slovenská republika

* Ol'ga Poniščiaková, tel.: +421415133216, e-mail: olga.ponisciakova@fpedas.uniza.sk
} 
conditions of transport companies as well as their subsequent use in profit management. To achieve the goal, several methodologies were used, not only for the partial goals - acquisition and processing of theoretical knowledge - but also for further solutions, proposals for the practical use of selected controlling tools in transport companies. The subject matter was solved with the use of selected qualitative methods, based on induction with an effort to observe, find out the regularity, draw conclusions and theories in order to obtain narrative outputs. Theoretical outputs are the result of processing available knowledge about controlling and its development, the practical level provides the result in the form of a proposal for the application of selected controlling tools in the conditions of transport companies operating in the Slovak Republic. The paper can be considered a relevant source of knowledge and understanding of the issues addressed, offers a methodological proposal, applicable in general to companies whose management decides to implement and use controlling tools.

management, transport, controlling, costs

\section{1 ÚVOD}

Vývoj podmienok, v ktorých podniky v súčasnosti napíňajú svoje poslanie sa mení a napreduje vel'mi intenzívne nielen z hl'adiska vývoja determinujúcich faktorov, ale aj dopadov na vnútorné prostredie podnikov samotných. Šukalová (2012) ukázala, že podnikatel'ské prostredie sa dnes vyznačuje globalizáciou a internacionalizáciou. Tieto účinky sa vzt’ahujú na všetky segmenty neustálej zmeny spoločnosti. Zmena je určitá variácia, vzrušenie, nepravidelnost', prekvapenie, niečo, s čím sa počíta. Manažérska práca sa v súčasnom období stáva náročnejšou. Medzi moderné vybavenie manažérov patrí znalost' riadenia zmien. V kontexte dynamizujúcej sa globalizácie a jej dôsledkov je irelevantné, či ide o podniky výrobné, alebo poskytujúce služby. Zmeny prostredia externého vyvolávajú potrebu reakcie zmien prostredia interného. Tento jav je vyvolaný zvyšujúcou s komplexnost’ou zmien vonkajšieho prostredia a dynamikou zmien, ktoré predstavujú hlavné atribúty formovania turbulentného podnikatel'ského prostredia. Jednou z interných podnikových oblastí, ktorej pôsobnost' je nielen možné, ale v maximálnej miere nutné inovovat', je tzv. hodnototvorna oblast', produkujúca paradigmicky spotrebu, ale následne aj pridanú hodnotu. $\mathrm{V}$ každom podniku je tvorba pridanej hodnoty náročná, $\mathrm{v}$ podmienkach dopravných podnikov však nepomerne viac. Dôvodom je samotný produkt a jeho špecifická charakteristika, ktorá obmedzuje vzhl'adom na vlastnosti prepravných služieb mnohé devízy produkcie hmotnej povahy, ale rovnako aj klesajúca atraktivita produktu v očiach spotrebitel'ov, ovplyvnených individuálnymi preferenciami a globalizáciou. Problematika súčasného riadenia dopravných podnikov je charakteristická limitovaným diapazónom manažérskych nástrojov pre riadenie s pridanou hodnotou. Dosahovanie ziskovosti bez negatívnych dôsledkov na tých, ktorým je prepravný produkt určený, je faktom, ktorý núti manažment dopravných podnikov hl'adat' nové alternatívne postupy a to s dôrazom na strategické postavenie $\mathrm{v}$ budúcnosti. Okrem tejto skutočnosti potrebu inovácie riadenia vyvoláva pretrvávajúce používanie tzv. tradičných nástrojov riadenia hodnototvornych veličín (tradičné riadenie nákladov alebo ich kalkulovanie), v podobe základnej účelovej, často len operatívnej evidencie nákladov a kalkulačného systému, ako nástoja na ich riadenie, rovnako založenom na tradičných kalkulačných druhoch a metódach. Treba však mat' na pamäti, ako Lazar (2012) ukázal, že finančné účtovníctvo sa nezaoberá otázkami riadenia účtovných jednotiek ako celku ani ich nižších organizačných zložiek, ani samo o sebe nerieši problém, ako dospiet' $\mathrm{k}$ údajom o množstve a cene vyprodukovaných, ale nerealizovaných zásob (nedokončenej výroby, polotovarov a výrobkov, ktoré podnik vytvoril vlastnou činnost'ou. Tieto údaje finančné účtovníctvo bežne neposkytuje. Preto je treba $\mathrm{v}$ účtovnej jednotke organizovat' ešte d’alšie evidenciu, ktorá sleduje hospodárenie vo vnútri účtovnej jednotky. Jednou z ciest, ako riadenie dopravných podnikov optimalizovat', je zavedenie funkčného systému controllingu, ktorý umožňuje odhal'ovanie možných rizík a príležitostí, definovanie alternatív rozhodovania a činností, ako aj informovanie manažmentu o dosiahnutých výsledkoch v kontexte tých želaných. O jeho významnosti nepochybuje ani Bedenik Osmanagic (2015), ked’ tvrdí, že controlling je jedným z nových prístupov, ktoré pomáhajú manažmentu lepšie sa prispôsobovat' novým okolnostiam, budovat' dôležité a živé organizácie schopné čelit’ novým výzvam. Svoju ambíciu napíňa prostredníctvom rôznych nástrojov, medzi ktorými 
nezastupitel'né miesto má oblast' nákladov a ich riadenia. Inovatívnost' controllingu sa následne zobrazuje pri využití jeho špecifických nástrojov aj v reporting - výkazníctve, ktoré je nástrojom controllingu prispôsobené a tým ovel'a efektívnejšie. Je dôležitou súčast’ou controllingového systému a prínosné je najmä v schopnosti pretvárat' informácie z tradičných nástrojov riadenia do nových operatívnych správ, výkazov, alebo štatistík. Ciel'om reportingu je poskytnút' manažmentu kvalitné portfólio informácií potrebných pre riadenie a rozhodovanie nielen operatívne, no najmä strategické. Príspevok prináša analýzu controllingových nástrojov s ohl’adom na ich uplatnenie v riadení dopravných spoločností. Dôraz je kladený najmä na controllingové riadenie nákladov, ich controllingovú kategorizáciu v špecifických podmienkach dopravných podnikov, ako aj ich následné využitie pri riadení zisku. Zameriava sa teda na analýzu spomínaných dôležitých parametrov controllingového výkazníctva v podmienkach dopravných podnikov a na návrh tvorby controllingových reportov pre dopravné spoločnosti.

\section{CONTROLLING, CONTROLLINGOVÝ REPOTING A VÝZNAM PRE RIADENIE}

Pojem controlling sa často sa spája otázkou, aký význam pre manažérov má a k opodstatneniu jeho využívania prispieva aj rad definícií. Drucker (2006) označil toto slovo ako „ambigous word,“ čo v preklade znamená nejednoznačné slovo. Rathe (1960) vo svojom výskume zistil, že len pre anglo-americké krajiny existuje viac ako 50 rôznych významov slova controlling. Okrem toho, že je označením pre organizovanie, plánovanie, kontrolu a iných činností, je aj ústrednou funkciou pre manažment. Podl'a Barana (2006) controlling môže byt' pre podnik prospešný, ak je jeho orientácia nasmerovaná na dosahovanie všetkých ciel'ov spoločnosti. Zároveň však treba pripomenút', že implementácia controllingu do podniku nie je taká jednoduchá, ako by sa na prvý pohl'ad mohla zdat'. Vyžaduje si špeciálu prípravu nielen z organizačného, ale predovšetkým $\mathrm{z}$ personálneho hl'adiska. Z prieskumu $\mathrm{v}$ chorvátskych podnikoch vyplýva, že implementácia sa zvyšuje, ked' sa majitelia nepodiel'ajú na manažmente, ale aj ak rastie vel'kost' podniku. Okrem toho sa prieskumom preukázalo aj efektívnejšie využívanie účtovných informácií (Spac et al. 2009).

O pozitívnom vplyve controllingu na riadene svedčia rôzne štúdie a výskumy. Jedným z nich je realizovaný prieskum v Pol'sku a Chorvátsku, zameraný na prínos controllingu k efektívnemu podnikaniu. Z jeho výsledkov vyplýva, že podniky pocit'ujú riadenie ako efektívnejšie po zavedení controllingu a to predovšetkým vd’aka identifikácii rizika a eliminácii predpojatých rozhodnutí manažmentu (TodorovićDudić et al., 2016).

Základnou úlohou controllingu je jeho pomoc manažmentu pri riadení zisku. Zisk spoločnosti je priamo ovplyvňovaný jej nákladmi, ked'že zisk predstavuje rozdiel medzi výnosmi a nákladmi. Náklady sú vo všeobecnej rovine charakterizované ako výdavky ekonomických zdrojov vynaložené na konkrétne plnenie podniku. V praxi to znamená, že controlling poskytuje informácie o štruktúre nákladov podl'a miesta ich vzniku a rovnako aj o dôvode ich vzniku. Do dnešnej podoby s príslušnou filozofiou, ciel'mi a funkciami sa controlling prepracoval a etabloval postupným vývojom a to aj v slovenských podnikoch, aj ked' vel'mi pomaly. Časopis Trend cituje názor profesorky Kalafutovej, ktorá tvrdí, že hl'adanie odpovedí na otázky, prečo sa neplní plán zisku, alebo fakt, že finančný riaditel' vidí dôvod v nesplnení predpokladov tržieb a šéf predaja vysvetl'uje, že tržby by sa splnili, keby sa boli dodržali termíny dodávok, d'alej, že výrobár sa vyhovára, že u nich to nestálo, haprovala technická príprava výroby - bol dôvod, prečo manažéri potrebovali controlling (Kalafutová a Poor, 2020). Controlling nie je ani účtovníctvo, ani reporting - hoci na nich stavia. Ide d’alej, zbiera informácie zo všetkých úrovní podniku - od montérov, skladníkov, cez vedúcich výroby, administratívy, účtovníctva až po manažment. Tie potom vyhodnocuje tak, aby firma zistila, v akých procesoch vznikajú aké náklady. Z nich sa dá určit', čo a ako treba zmenit'. Napríklad ktorých výrobkov treba vyrábat' viac a ktorých menej, kde sú zbytočné nákladové rezervy a ktorých zákazníkov sa neopláca mat'. Controlling rieši typický problém každej firmy - ako zvýšit' zisk, vysvetl'uje riaditel' firmy Empiria consult a.s., Bratislava Juraj Poór pre vyššie uvedený časopis (Kalafutová a Poor, 2020). Hl'adanie nového zisku či starých zbytočných nákladov je však iba jedna čast', ktorou sa controlleri zaoberajú. 
Kritické miesto má controlling najmä vo vel'kých podnikoch, so zložitejšími výrobnými procesmi. Presah tradičného reportingu možno interpretovat' prostredníctvom významného nástroja controllingu, ktorým je controllingový reporting. Patrí medzi vel’mi známy a rokmi osvedčený nástroj controllerov. Ide o metodický postup, vd’aka ktorému sa dostávajú informácie od controllerov k manažérom. Tento prenos informácií však nie je jednorazový ani príležitostný, ale systematický a priebežný. Využíva pritom možnost' tieto informácie aj postupne dotvárat' do šírky aj híbky a neustále ich aktualizovat'. Reporting by mal fungovat' rovnako dobre ako informačný systém podniku, avšak vo väčších spoločnostiach sa vytvoril controllingový informačný systém, ktorý tvorí nadstavbu podnikovému informačnému systému. Vrcholový manažment požaduje súhrnné informácie o podniku ako celku, čo zahŕňa nielen informácie o internom prostredí. Požaduje informácie aj o možných zmenách v externom prostredí, prípadne aj detailnejšie informácie o čiastkových procesoch, ktoré manažérom pomôžu skúmat' príčiny, navrhovat' varianty riešení, alebo pochopit' súvislosti medzi zdanlivo nesúvisiacimi procesmi. Manažéri nižších úrovní vytvárajú dopyt po informáciách, týkajúcich sa oblastí, v ktorých pôsobia, ktoré im umožňujú riešit' špecifické problémy a rovnako aj prijímat' rozhodnutia. $V$ tomto prípade to môžu byt' informácie o nákladoch, vývoji predaja, obratoch aktív, a podobne (Papula et al., 2017).

Správnost’ informačného prepojenia je podmienená aj vhodnou inštitucionalizáciou controllingu. Je možné implementovat' ho do rôznych pôvodných podnikových organizačných štruktúr, ale podniky môžu využit' aj externého controllera, teda špecialistu mimo podniku. $V$ takom prípade je zavedenie controllingu omnoho rýchlejšie a eliminuje sa vzniku konfliktov. Otázne však je, či dokáže controller detailne poznat' vnútorný stav podniku. Prieskum realizovaný v Srbsku poukázal na to, že len približne 30 \% zo 107 oslovených podnikov využíva služby externého controllingu (Todorović -Durić et al., 2017). Na druhej strane však poskytnutie samostatného útvaru controllingu prispieva k efektívnosti podnikania, predovšetkým prostredníctvom zabezpečenia transparentnosti podnikatel'ského výsledku a obchodných procesov (Vuko et al., 2013).

Dôležitou podmienkou pre naplnenie poslanie controllingového reportingu je určitá modifikácia parametrov, evidovaných a riadených tradičným spôsobom. Inými slovami, ide o určitú modifikáciu tradičného reportingu. Tá vychádza z modifikácie jeho zdrojových vstupných nástrojov. K takým možno zaradit' napríklad finančno- ekonomickú analýzu. Jednou z najužitočnejších finančných analýz je jej konkrétna metóda, pretože má potenciál nájst' odpovede týkajúce sa finančného zdravia ktorejkol'vek spoločnosti. Vo všeobecnosti sú výsledky finančnej analýzy hodnotné, pretože predstavujú spoločnost’ a jej obchodný úspech obchodným partnerom (existujúcim aj potenciálnym) a podl'a príslušných finančných údajov spoločnost' vnímajú, hodnotia a určujú obchodné podmienky pre budúcnost' (Achimská a Kramárová, 2011). Ďalšou možnost'ou je využitie potenciálu finančného účtovníctva, založeného na legislatívne zavedenom evidovaní nákladov a výnosov za uplynulé hospodárske obdobie. Problémom je aj skutočnost', na ktorú poukázal Eschenbach (2004), že štandardný reporting je značne rozšírený, avšak kvalita zistených reportingových systémov a výsledky reportingových metód ukazujú, že existuje ešte značná rezerva v rozvoji. Vel'mi dôležitou veličinou reportingu (výkazníctva) sú náklady. Predstavujú vel'mi dôležitú súčast' ekonomického riadenie. Ich výška ovplyvňuje konečný zisk a štruktúra z hl'adiska účtovného je znázornená v účtovej osnove, v ktorej všetky druhy sú usporiadané v účtovej triede číslo 5. Zoskupujú sa do jednotlivých skupín a označujú príslušným spoločnými pomenovaním. V priebehu časového obdobia dochádza $\mathrm{k}$ pohybu jednotlivých typov nákladov (rovnako ako výnosov). Vzniknuté zmeny možno zachytit’ $v$ rámci finančného účtovníctva pomocou príslušných účtovných dokladov (napr. faktúry) na príslušných účtoch. $V$ praxi to znamená, že sa daný doklad o pohybe určitého nákladu zúčtuje na stranu dal, alebo má dat' odpovedajúceho účtu. Uvedené skupiny nákladov a rovnako aj prirad'ovanie nákladov k týmto skupinám sa uskutočňuje podl'a účtovných pravidiel a úzko súvisí aj s predpísanou tvorbou výsledovky. 


\subsection{Controlling a riadenie nákladov}

Tradičné hodnototvorne riadenie je vo vel'kej miere podložené výstupmi z finančného účtovníctva. $\mathrm{Z}$ charakteristiky controllingového riadenia však vyplýva potreba koncentrácie sa na nasledovné okruhy problémov (Poniščiaková a Gogolová, 2017):

- Z podrobnej diferenciácie nákladov do uvedených nákladových skupín, tak ako sa tvoria v účtovníctve vyplýva, že môže dôjst' k určitej neprehl'adnosti, spomal'ujúcej rozhodovanie. Preto vedenie podniku, ak chce dodržat' zásady controllingu, musí toto členenie prehodnotit'. V konečnom dôsledku ide o zúženie okruhu nákladových skupín do takých, ktoré sú z hl'adiska riadenia najdôležitejšie. Teória odporúča navrhnutie monitorovania maximálne 10 nákladových druhov jednotlivo a z ostatných vytvorenie jedinej položky - ostatných nákladov.

- Okrem uvedeného problému je potrebné si uvedomit’ mieru informovanosti, ako ju poskytuje účtovné hl'adisko členenia nákladov. Pre vnútropodnikové riadenie sa ukazuje byt' nedostatočnou. Riadenie ziskom totiž diferencuje náklady aj z hladiska ich vzt’ahu k podnikovým výkonom, ktoré v rámci účtovníctva absentuje. Tak dochádza k tomu, že náklady priamo súvisiace s produkciou sa miešajú s takými, ktoré slúžia len na prevádzku a priamo s objemov výkonov nesúvisia. Tento, pre controllingové riadenie negatívny jav, možno eliminovat' preskupením nákladov podl'a spomínaného hl'adiska na závislé - výkonové a nezávislé - pohotovostné náklady.

Výber 10 druhov nákladov sa uskutočňuje na základe určitých kritérií. Aj d’alšia ich diferenciácia na náklady závislé a nezávislé sa odvíja od určitých zákonitostí. Sú nimi príčiny vzniku nákladov. Sú jedným z najdôležitejších aspektov vnútropodnikového riadenia. Jeho snahou je dodržanie princípu príčinnosti (kauzality), umožňujúceho odhalenie závislostí na určitých vývojoch v podniku, na rozdiel od riadenia vychádzajúceho z finančného účtovníctva, vedeného princípom jednoznačnosti a zúčtovávania dokladov. Controllingové riadenie sa preto orientuje, na nasledovnú diferenciáciu nákladov:

Výkonové náklady: sú zapríčinené priamo výkonom, preto sa nazývajú tiež priame. Do výkonu (výrobok, služba) vstupujú priamo, a preto sú mu aj priamo priraditel'né. Tvoria kalkulačnú základňu pri výpočte minimálnej cenovej hranice. Patria sem výrobné mzdy, výrobný materiál a pod.

Pohotovostné náklady: sú náklady, ktoré s výkonom priamo nesúvisia, teda do výrobku, či služby priamo nevstupujú. Slúžia na prevádzku ako takú a patria k nim náklady na priestory, reklamu apod. Teoreticky sú najväčším stratovým rizikom, lebo keby podnik nič nevyrobil, tak vykázaná strata za sledované obdobie by zodpovedala výške týchto nákladov. Členia sa d’alej na:

Pohotovostné náklady I nie sú prirad'ované priamo k výkonu, ale závislé na jednotlivých vývojoch v podniku (skupine výrobkov, služieb, funkčných okruhoch, skupinách zákazníkov), ku ktorým sú prirad'ované. Prirad'ovanie si nevyžaduje použitie špecifického kl'úča (náklady na poštovné, telefón, kancelárske potreby).

Pohotovostné náklady II sú rovnako závislé na vývojoch v podniku, ale priradit' ich bez použitia špecifického kl'úča, alebo metódy nemožno (reprezentačné náklady, príspevky, dane). Vrátime sa ešte ku kritériám výberu nákladov, ktoré eliminujú evidenciu nákladov na maximálne 10 nákladových druhov.

- Postupnost' dôležitosti nákladov je daná váhou ich významu. Tá sa vyjadrí percentuálnym podielom jednotlivých podnikových nákladov na celkovom výnose podniku, ktorý predstavuje $100 \%$.

- Odhad poradia nákladov sa predbežne určí z výsledovky, presnejšie z účtovnej triedy 5.

- V d'alšom kroku sa určí, či takto stanovené poradie nákladov korešponduje s poradím nákladov v podniku, stanovenom podl'a ich dôležitosti. Môže sa totiž stat', že niektoré náklady, ktoré majú vysoký percentuálny podiel, nie sú pre podnik z hl'adiska riadenia tak dôležité a naopak. Je nutné takýto prípad zohl'adnit' a vytvorit’ novú hierarchiu nákladov. 
- Poradie nákladov sa zostaví aj zoskupovaním nákladov príbuzného charakteru do jednej spoločnej skupiny. Napríklad priestorové náklady budú v sebe zahŕňat' nielen náklady na opravy, nájom, ale aj na vykurovanie, energiu, čistenie a pod.

\subsection{Controlling a jeho význam pre riadenie $\mathrm{v}$ dopravných podnikoch}

V dopravnom podniku, $v$ ktorom rešpektujeme niektoré špecifické druhy nákladov, má plán nákladových druhov nasledujúcu podobu, uvedenú v tab. 1.

Tab. 1 Plán nákladových druhov dopravného podniku; zdroj: vlastné spracovanie; zdroj: vlastné spracovanie

\begin{tabular}{|c|c|c|c|c|c|}
\hline čísla & $\begin{array}{l}\text { plán nákladových } \\
\text { druhov }\end{array}$ & & $\begin{array}{l}\text { výkonové } \\
\text { náklady }\end{array}$ & $\begin{array}{l}\text { pohotovostné } \\
\text { náklady I }\end{array}$ & $\begin{array}{c}\text { pohotovostné } \\
\text { náklady II }\end{array}$ \\
\hline & číslo účtu & Názov účtu & & & \\
\hline & $\mathrm{a}$ & $\mathrm{b}$ & $\mathrm{c}$ & $\mathrm{d}$ & $\mathrm{e}$ \\
\hline 01 & & $\begin{array}{l}\text { priamy } \\
\text { materiál }\end{array}$ & $*$ & & \\
\hline 02 & & osobné náklady & $*$ & & \\
\hline 03 & & odpisy DM & $*$ & & \\
\hline 04 & & $\begin{array}{l}\text { opravy a } \\
\text { udržiavanie }\end{array}$ & & & \\
\hline 05 & & $\begin{array}{l}\text { ostatné } \\
\text { prevádz. n. }\end{array}$ & $*$ & & \\
\hline 06 & & $\begin{array}{l}\text { prevádzková } \\
\text { réžia }\end{array}$ & & $*$ & \\
\hline & & správna réžia & & & $*$ \\
\hline
\end{tabular}

Plán teda tvorí súčast' reportingu, ktorý využíva controlling. Samostatne, hoci v nadväznosti na diferenciáciu nákladov v účtovnej osnove by nemal vel'ké využitie, je jeho sprostredkujúcou súčast'ou pre následné formovanie výkazníckeho aparátu, slúžiaceho pre riadenie hodnototvornych veličín. Je dôležité mat' stále na pamäti, že podstatou controllingu je riadenie zisku. Vychádzajúc z tejto poučky je potrebné sa zamysliet' nad tým, ako zisk vzniká. Nebolo by totiž správne si pod pojmom riadenie zisku predstavovat', že bude zabezpečený len monitorovaním tejto veličiny. Riadenie zisku totiž znamená riadenie tých veličín, ktoré zisk vytvárajú, ktoré sa na ňom podiel'ajú. Logicky je teda potrebné uvažovat' pri riadení zisku v prvom rade $s$ nákladmi a výnosmi, ktoré sa v hospodárení na ziskovosti, alebo strate podniku podiel'ajú v najväčšej miere. $V$ analytickom uvažovaní treba pokračovat' d'alej, lebo podobne, ako zisk, aj náklady a výnosy nie sú základnými, ale tvorenými veličinami. Treba ich preto diferencovat' na položky, ktoré riadenie zisku umožnia. Vnútropodnikovým nástrojom na tento účel v podniku je príspevok na úhradu, tiež nazývaný krycí príspevok, ktorý vo svojej ekonomickej interpretácii skutočne znamená výšku (mieru), v akej sú pokrývané jednotlivé skupiny činností a nákladov z plánovaných, či skutočne dosahovaných výsledkov firmy.

Pri výpočte príspevku na úhradu postupujeme nasledovne:

hrubý obrat (celkové tržby, predajná cena resp. výnosy)

- daň z pridanej hodnoty

- položky znižujúce tržby

čistý (netto) obrat 
potom: príspevok na úhradu = prebytok netto obratu (predajných cien, resp. tržieb - v doprave) nad priamymi (výkonovými resp. variabilnými) nákladmi (vid’ obr. 1).

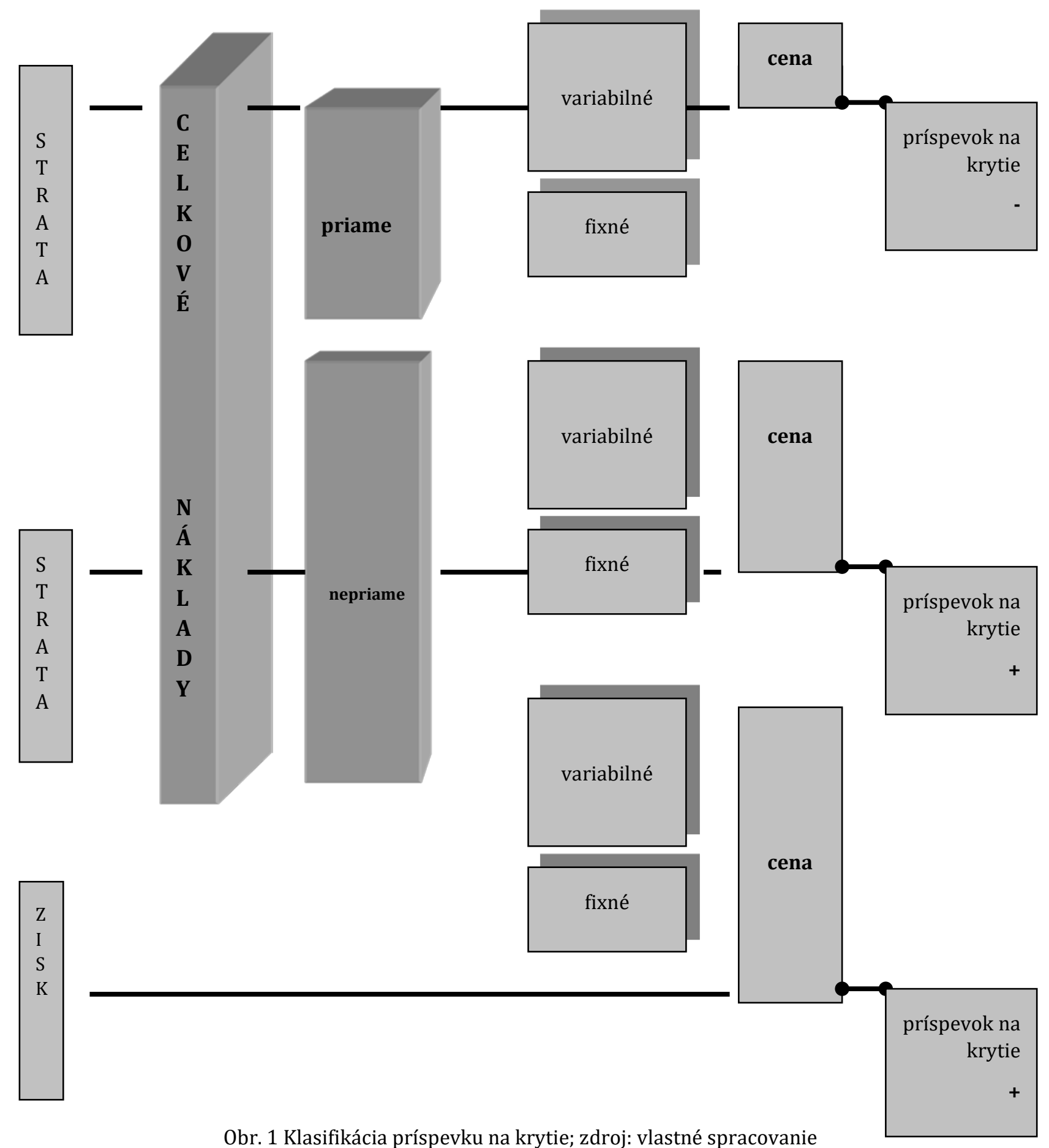

Ročné vyjadrenie príspevku na úhradu predstavuje percentuálnu sadzbu z obratu, ktorú treba ako príspevok na úhradu priemerne dosiahnut' na výkon (výrobok, službu), aby sa splnil ciel’ový zisk. Z toho plynie aj funkcia príspevku na úhradu, ktorá spočíva jednak v krytí pohotovostných nákladov (ktoré, ako sme už uviedli, predstavuje stratové riziko) a jednak v nástroji na dosiahnutiu zisku. Je to z toho dôvodu, že každý vznik výkonu spôsobuje vždy vznik výkonových nákladov a príspevku na úhradu, ale nie pohotovostné náklady a zisk. Ak sa vrátime k úvodnej úvahe o nutnosti sledovat' na zabezpečenie zisku zložky, ktoré k jeho vytvoreniu prispievajú a nie len samotnú veličinu zisku, vyplýva pre podnik potreba 
evidencie netto obratu, priamych výkonových nákladov, pohotovostných nákladov a ciel’ového zisku. Príčiny vzniku nákladov, súvisiace s ich priamym, alebo nepriamym vzt’ahom k výkonu, sa odrážajú vich príslušnej diferenciácii na náklady výkonové a pohotovostné, ktoré ešte možno rozčlenit’ na pohotovostné I a pohotovostné II. Odrazom uplatnenia spomínaného princípu je tab. 2 controllingového výkazníctva, ktorá slúži na zist’ovanie výsledku.

Tab. 2 Tabul'ka controllingového výkazníctva dopravného podniku; zdroj: vlastné spracovanie

\begin{tabular}{|c|c|c|c|c|c|}
\hline riadok & položky & okruh/výrobok & hodnota & obdobie & ukazovatel' \\
\hline 00 & Tržby z dopravy 3 & & & & \\
\hline 01 & Ostatné tržby z dopravy & & & & \\
\hline 02 & Zníženie tržieb & & & & \\
\hline 03 & Tržby z ostatnej činnosti & & & & \\
\hline 04 & Spotreba mat. a surovín & & & & \\
\hline 05 & Čistý výnos & & & & \\
\hline 06 & Výrobné mzdy & & & & \\
\hline 07 & Ostatné priame náklady & & & & \\
\hline 08 & Výkonové náklady & & & & \\
\hline 09 & Príspevok na úhradu I. & & & & \\
\hline 10 & Prevádzková réžia & & & & \\
\hline 11 & Náklady na ostatnú činnost' & & & & \\
\hline 12 & Pohotovostné náklady I & & & & \\
\hline 13 & Pohotovostné náklady II & & & & \\
\hline 14 & Prevodový mostík & & & & \\
\hline 16 & Zisk / strata & & & & \\
\hline
\end{tabular}

\section{DEFINOVANIE DRUHEJ ROVINY REPORTINGU V DOPRAVNÝCH PODNIKOCH}

V podniku sa tvorba druhej roviny výkazníctva opiera o dodržovanie určitých zásad, vychádzajúcich okrem existujúceho usporiadania jednotlivých vnútropodnikových jednotiek aj z rešpektovania princípov controllingu. $\mathrm{K}$ nim patrí fakt, že $\mathrm{v}$ začiatočných krokoch zavádzania treba upustit' od náročných požiadaviek a zamerat' sa len na najdôležitejšie (základné) rozdelenie. To predpokladá vol'bu maximálne piatich jednotiek, ku ktorým bude možno adresne pridelit' nositel'a zodpovednosti, za predpokladu vol'by niektorého z nasledovných princípov:

Podl'a služieb, resp. produkcie je možné vytvorit’ zúčtovacie strediská vtedy, ked' je možné jednotlivo pre každý výrobok, alebo skupinu určit' suroviny, postupy výroby, štruktúra nákladov, kalkulačné postupy.

Zodpovednostné okruhy sú vhodné pre strediská s jednoznačne určenými funkčnými okruhmi, s rozdelením zodpovedností, alebo ak existujú rozdielne dielne, či divízie, poprípade rôzne odbytové organizácie.

Rozdelenie podl'a zákazníkov je vhodné použit' vtedy, ak podnik má rozdielne odbytové cesty alebo skupiny zákazníkov ( $\mathrm{v}$ závislosti od ich vel'kosti). $\mathrm{V}$ dopravnom podniku možno interpretovat' uvedené diferencovanie podl'a ciel’ov ciest jednotlivých zákazníkov.

\footnotetext{
${ }^{3}$ Finančné výkony v autobusovej doprave sú tržby z predaja cestovných lístkov. Sú ovplyvnené regulovanými cenami cestovného, a preto spôsobujú nepružnost' vzt'ahu medzi ponukou a dopytom. Ovplyvňujú výsledok hospodárenia.
} 


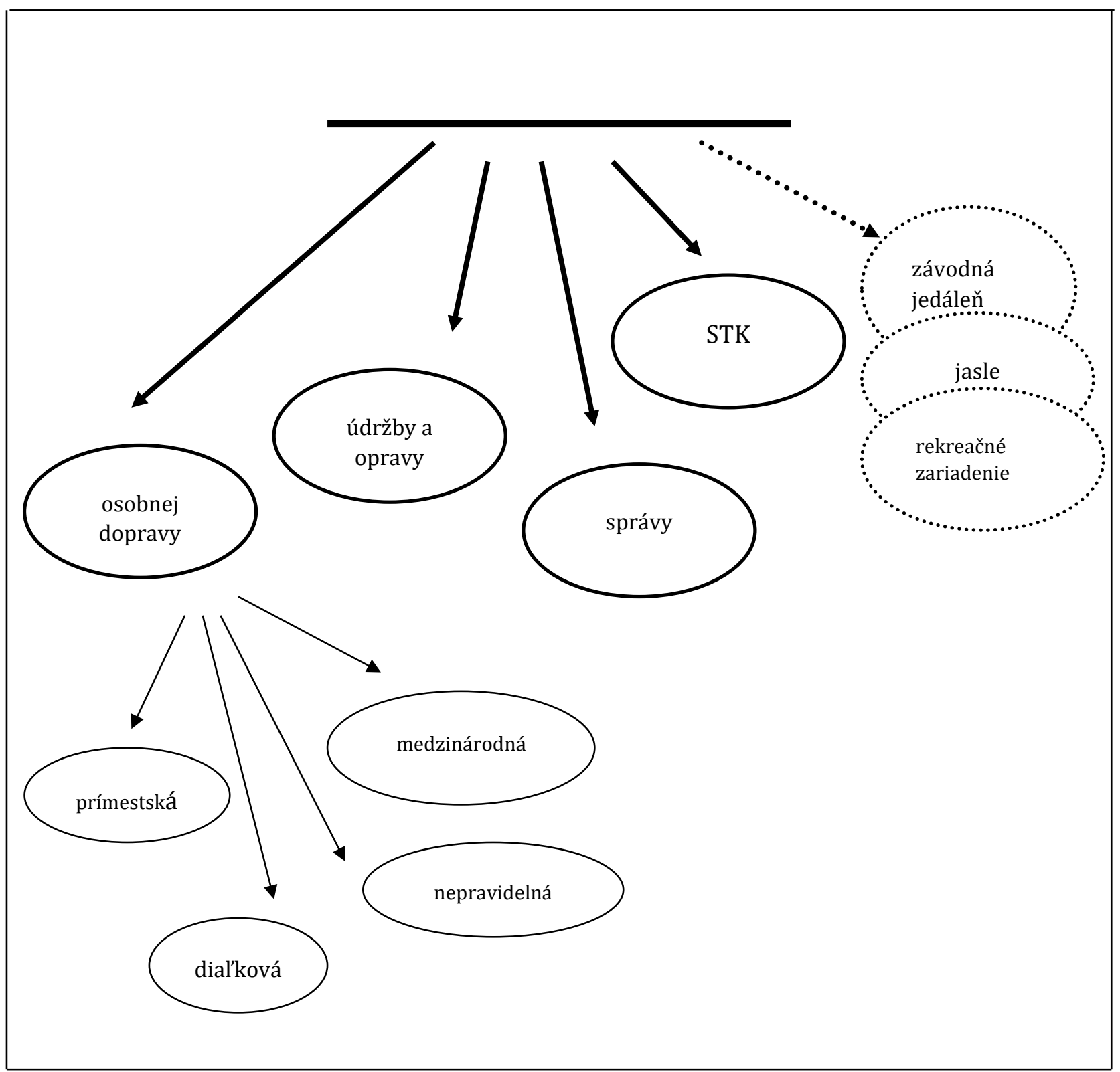

Obr. 2 Návrh nákladových stredísk dopravného podnik ; zdroj: vlastné spracovanie

Tie sa neskôr môžu stat’ východiskom pri tvorbe organizačnej schémy podniku. Okrem toho je potrebné zohl'adnit' aj existenciu takého nákladového strediska, ktoré zahrňuje všetky funkcie, slúžiace podniku ako celku, označenom ako centrálna vnútropodniková jednotka (centrálna VPJ). Činnost' dopravného podniku spočíva v poskytovaní možnosti premiestnenia - prepravy na rôzne miesta v rámci mesta, jeho okolia, $\mathrm{v}$ rámci štátu ako aj za hranice. Vytvárajú sa tak skupiny zákazníkov podl’a toho, o ktorú službu má ten ktorý zákazník záujem, z čoho plynie možnost' zohl'adnit' členenia podl’a zákazníkov, alebo skupín zákazníkov (vid'. obr. 2).

\section{DISKUSIA}

Doprava predstavuje neoddelitel'nú súčast' l'udskej spoločnosti, ktorej vývoj je úzko spojený s výmenou tovarov, a teda vývojom dopravy, slúžiacej na realizáciu tejto výmeny. Dopravné podniky poskytujú svojim zákazníkom prepravné služby, ktorých význam je značný. Význam prepravných služieb sa napíňa, ak sú splnené požiadavky, ktoré sa vo všeobecnosti kladú na dopravu. K najdôležitejším patria: rýchlost', spol'ahlivost', pravidelnost', bezpečnost', plynulost', pohodlnost', prispôsobivost'. Ak sa uvedené požiadavky splnia, doprava nadobúda svoj význam a je funkčná. Konkrétnejšie získava nasledujúce funkcie: 
sprostredkovaciu, inovačnú a sociálnu. Svoje postavenie si však dopravné podniky musia neustále obhajovat', aby úspešne odolali konkurenčným tlakom a vplyvom globalizácie. Zo spektra spôsobov, ako uspiet', sme sa v príspevku zamerali na controlling a využitie jeho nástrojov s priamym dopadom na reporting $\mathrm{v}$ dopravných podnikoch. Reporting je totiž neoddelitel'nou súčast’ou controllingu a controlling je spol’ahlivým nástrojom na podporu riadenia a rozhodovania v dopravných podnikoch. Generuje informačný podklad pre manažérske rozhodnutia. Tak, ako bolo v predchádzajúcej kapitole predstavené pre potreby dopravných podnikov, vo všeobecnej rovine potvrdzuje aj Fibírová a Šoljaková (2011) ked' tvrdí, že môže tvorit’ komplexný systém vnútropodnikových správ a výkazov syntetizujúci informácie pre riadenie podniku nielen ako celku, ale aj jeho základných organizačných jednotiek. Úloha controllingového oddelenia dopravného podniku teda spočíva v príprave takých správ, z ktorých manažéri dostanú tie najpodrobnejšie informácie. Pri návrhu a implementácii reportingového systému by mal byt' rešpektovaný nasledujúci postup: identifikácia užívatel'ov výkazu a ich potrieb - z hl'adiska obsahu, formy, času, diferenciácia výkazu na interných a externých užívatel’ov, vol'ba vhodnej formy výkazu - tlačená, elektronická podoba alebo ich kombinácia, návrh jednotného dizajnu (nie časté zmeny), distribúcia výkazu - klást' dôraz na oddelenie dôverných informácií, využívanie spätnej väzby od používatel'ov k zlepšovaniu systému reportingu. Obsah, úprava a početnost' zhotovovania správ a výkazov závisí od potrieb konkrétneho podniku. Pre zostavenie reportingovej správu (report) v požadovanej štruktúre je potrebná dispozícia objektívnych informácií. Pri tvorbe reportu sa využívajú nielen informácie z finančného účtovníctva, ale aj variantné zdroje informácií (vid' obr. 3).

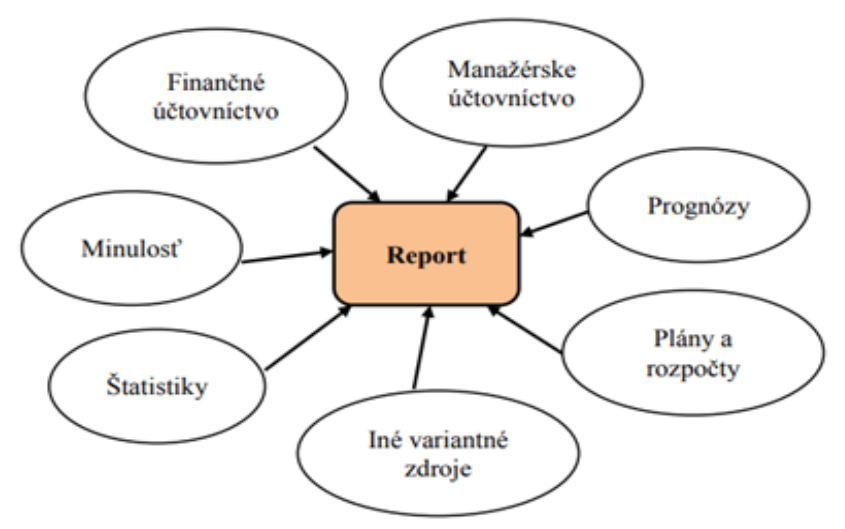

Obr. 3 Variantné zdroje informácií pre zostavenie reportingovej správy, zdroj: Kádárová (2011, s. 2)

Vo väčšine prípadov podniky zostavujú a využívajú mesačný a štvrt'ročný reporting. Analyticky sledujú najvýznamnejšie položky jednotlivých nákladov, výnosov, obežných aktív (pohl'adávok, zásob) a záväzkov. Aj ked’ môže byt' štruktúra interných správ rôzna, zvyčajne sa stretávame s členením na súhrnný reporting a niekol'ko čiastkových reportov podl'a jednotlivých oblastí podnikových činností. Súhrnný reporting obsahuje základné finančné ukazovatele hospodárenia podniku ako celku za dané obdobie, ich porovnanie s plánovanými hodnotami, prípadne porovnanie s hodnotami minulého obdobia. Fibírová a Šoljaková (2011) ukázali, že v správach je vel’mi dôležitý i komentár, ktorý upozorňuje na mimoriadne odchýlky od plánovaného zámeru a analyzuje ich príčiny. Čiastkové reporty sú zvyčajne rozčlenené podl'a oblastí na obchodnú, výrobnú, personálnu, marketingovú a pod. Ich štruktúra vychádza zo zvyklostí a špecifík daného podniku. Súhrnný reporting obsahuje základné finančné ukazovatele hospodárenia podniku ako celku za dané obdobie, ich porovnanie s plánovanými hodnotami, prípadne porovnanie s hodnotami minulého obdobia. 


\section{ZÁVER}

Controlling predstavuje jednu z možností, ako podporit' efektívne hospodárenie v podniku. Je neoddelitel'nou súčast'ou moderného riadenia podniku, v ktorom sa viaže na celý jeho proces. Svojou integráciou procesov spracovania informácií, tvorbou analýz, podnikových plánov a kontroly sa stáva základom úspešnosti na trhu. Jeho úlohou je spracovávat' množstvo údajov a dát do prehl'adných reportov, ktoré obsahujú len tie najdôležitejšie, kvalitné a dôveryhodné informácie. Informácie sú totiž v súčasnosti vnímané ako jeden z kl'účových faktorov úspechu podniku, pretože znalost' a predpoved' toho, čo príde pomáha podporuje celkov strategické riadenie.

Dodržaním uvedených krokov sa podnik pri implementácii controllingového výkazníctva vyhne rôznym zbytočným prekážkam a vytvorí si tak základňu, na ktorej môže stavat' pri realizácii d'alších fáz, týkajúcich sa oblastí, do ktorých zasahuje. Platí totiž, ako tvrdí Tokarčíková (2011), že nové inovácie z nových technológií, metód a príležitostí môžu pre podnik priniest' značné výhody. Aby medzi tradičným účtovným riadením a controllingom existoval súlad a vzájomne si nekonkurovali, je potrebné pripomenút' dôležitost' vymedzenia jasného vzt’ahu medzi manažmentom a controllingom. Faktom totiž zostáva, že manažment rozhoduje, nesie zodpovednost' a controlling len rozhodovanie podporuje svojimi inšpiráciami, hodnotením, analyzovaním a kontrolovaním. Controlling dáva odporúčania. Aby boli pre manažment použitel'né, musia byt' aj nástroje controllingu správne nastavené, čo platí aj pre reporting v dopravných podnikoch. $\mathrm{V}$

Všetky benefity controllingu s univerzálnou platnost'ou možno špecifikovat'. V príspevku sme najväčší dôraz kládli na špecifikáciu v dopravných podnikoch. Navrhli sme spôsob využitia controllingových nástrojov v spojitosti s riadením nákladov dopravných podnikov, ako aj s možnost'ou aplikovat' v týchto podnikoch controllingový reporting.

\section{Literatúra}

Achimská, V., Kramárová, K. 2011. Reducing of USP through the reduction of access points. POSTPOINT Open market - a challenge for postal services. International conference. Rajecké Teplice - Hotel Diplomat, 19.09.2011 - 20.09.2011. Žilinská univerzita v Žiline: Edis, s. 16-20.

Baran, D. 2006. Aplikácia controllingu v podnikovej praxi. Bratislava: Vydavatel'stvo STU.

Bedenik Osmanagic, N. 2015. The Challenge of Controlling. International Journal od Industrial engeneering and Management, 6(4), pp. 153-163.

Drucker, P. F. 2006. Management - budoucnost začíná dnes. Brno: Management Press.

Eschenbach, R. 2004. Controlling. Praha: ASPI.

Fibírová, J., Šoljaková, L. 2011. Reporting. Praha: Grada Publishing.

Kádárová, J. 2011. Reporting ako nástroj pre podporu manažmentu podniku. [online]. Dostupné z: URL: [https://www.sjf.tuke.sk/umpadi/taipvpp/2011/index.files/clanky/Jaroslava\%20Kadarova\%20Reporti ng.pdf]

Kalafutová, L., Poor, J. 2020. Controlling potrebuje kvalitný reporting, ide však d'alej. Trend, 21/2020. [Online]. Dostupné z: URL [https://www.trend.sk/financie/controlling-potrebuje-kvalitny-reporting-idevsak-dalej]

Lazar, J. 2012. Manažerské účetnictví a controlling. Bratislava: Grada Publishing.

Papula, J. et al. 2017. Manažérska ekonomika ako teória obohacovaná skúsenost'ami a trendmi $v$ manažmente. s. l. Bratislava: Wolters Kluwer SR.

Poniščiaková, O., Gogolová, M. 2017. Podnikový controlling. Žilina: EDIS. 
Rathe, A. W. 1960. Management Controls in Business. In Malcolm, D. G., Rowe, A. J. Management Control Systems. New York: Wiley.

Spac, D. et al. 2009. Controlling in Transition Environments: Empirical Evidence from Croatia. South East European Journal of economics and business, 4(1), pp. 63-80.

Šukalová, V. 2012. Change management - an important part of transport company management. Doprava a spoje internetový časopis, pp. 381-386. [Online]. Dostupné z: URL [http://fpedas.uniza.sk/dopravaaspoje/2012/2/sukalova.pdf]

Todorovic-Dudic, A. et al. 2016. Contribution of controlling to business efficiency. Conference FINIZ, 45, pp. 25-44.

Todorovic-Dudic, A. et al. 2017. Challenges and dilemmas of controlling in the republic of Serbia. Conference FINIZ. pp. 70-77.

Tokarčíková, E. 2011. Influence of social networking for enterprise's activities. Periodica Polytechnica: social and management sciences, 19(1), p. 39.

Vuko, T. et al. 2013. Controlling and busines efficiency. Croatian operational research review. Vol .4, pp. 4454 . 